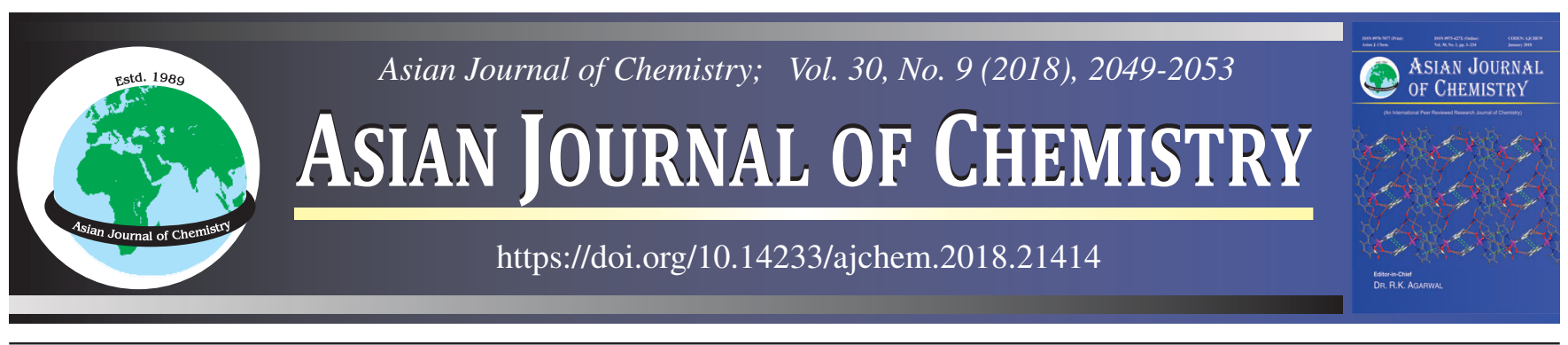

\title{
Synthesis, Characterization and Applications of Some \\ Azo Dyes Derived from Various Aromatic Amines
}

\author{
V.G. VIDYA and V. SADASIVAN ${ }^{*}$ \\ Department of Chemistry, University College, M.G. Road, Thiruvananthapuram-695 034, India \\ *Corresponding author: E-mail: vg_vidya@yahoo.co.in \\ Received: 28 April 2018; \\ Accepted: 7 June 2018; \\ Published online: 31 July 2018; \\ AJC-19019 \\ In this work, we report the synthesis of metal free dyes and their fastness properties. A series of monoazo dyes obtained by diazotization
of various aromatic primary amines and coupling with different components. One coloured Schiff base derived from triethylene tetramine
and N,N-dimethylbenzaldehyde was also synthesized. These coloured compounds were characterized by FTIR, UV-visible, ${ }^{1} \mathrm{H},{ }^{13} \mathrm{C} \mathrm{NMR}$
and ESI mass spectroscopic methods. The dyeing performance of all the compounds were evaluated on cotton fabric. They were applied
on bleached cotton fabric and their dyeing and fastness properties were assessed. The absorption spectra of the dyes are discussed with
regard to their structure. The structure of coloured dyes and Schiff base are proposed based on various spectroscopic data. The newly
synthesized group of monoazo dyes gives shades ranging from yellow to reddish orange with good light fastness and excellent wash
fastness. \\ Keywords: Azo dyes, Cotton fabric, Fastness properties. \\ ᄂ $-\ldots-\ldots-\ldots-\ldots-\ldots-\ldots-\ldots-\ldots-\ldots-\ldots-\ldots$
}

\section{INTRODUCTION}

Azo dyes are the most important class of dyes accounting for more than $50 \%$ of all commercial dyes or colourants. They have found many applications in various fields of science and technology $[1,2]$. The importance behind this study is to synthesize azo dyes containing heterocyclic rings due to their superior properties. The introduction of heterocyclic ring as coupling components have made possible the synthesis of good colourants with chromophoric strength and brilliant colours. Such dyes have high level dyeing properties and excellent fastness properties [3]. The usability of heterocyclic azo dye lies in the field of textiles, papers, leather, additives, food stuff, cosmetics, holographic data storage materials, xerography laser materials, laser printing, materials for organic solar cells and chemosensors, etc. [4-9].

Heterocyclic azodyes are found to be useful in second harmonic nonlinear optical material and optical switching devices [10-12]. The strong bathochromic effect of heterocyclic system is due to its diene character [13]. Towns [14] has reported the developments in azo dyes derived from heterocyclic azo components. A number of heterocyclic azo dyes and their derivatives are used as intermediates in dye stuff industry [15-21]. Focussed attention has been given to heterocyclic derivatives of azo dyes due to their diverse biological activities as antitumor, antiinflammatory, antibacterial and antifungal agents [22-24]. In this endeavour, a series of heterocyclic monoazodyes with good dyeing and fastness properties have been assessed.

\section{EXPERIMENTAL}

All the reagents and solvents for syntheses and analyses were of Merck products and used as supplied. FTIR spectra were recorded using $\mathrm{KBr}$ discs on a Perkin-Elmer spectrum 65 spectrometer. Elemental analyses were performed on a Vario EL-III CHN elemental analyzer. Electronic absorption spectral measurements of the dyes in methanol were conducted using Perkin-Elmer Lambda $25 \mathrm{UV}$-Vis spectrophotometer. ${ }^{1} \mathrm{H}$ and ${ }^{13} \mathrm{C}$ NMR spectra were recorded on a 400MHz FTNMR instrument. Mass spectra of the dyes and Schiff base obtained with ESI mass spectra. Fastness to light, sublimation and perspiration were assessed in accordance with BS: 1006-1978. The rubbing fastness test was carried out with a Crockmeter, Atlas in accordance with AATCC-1961 and the wash fastness test in accordance with IS:765-1979. The details of the method of colour

This is an open access journal, and articles are distributed under the terms of the Creative Commons Attribution-NonCommercial 4.0 International (CC BY-NC 4.0) License, which allows others to copy and redistribute the material in any medium or format, remix, transform, and build upon the material, as long as appropriate credit is given and the new creations are licensed under the identical terms. 
fastness test were described in literature [25]. The dyeing of cotton fabrics were carried out according to the literature [26].

Synthesis of dyes: All the dyes were prepared by the standard procedure of diazotization of amines $[27,28]$ followed by coupling with corresponding compounds.

Synthesis of 5-(2,3-dimethyl-1-phenyl-3- pyrazolin-5one-4-ylazo)-1H-pyrimidine-2,4-dione (dye I): A solution of 4-aminoantipyrine $(0.01 \mathrm{~mol})$ was prepared in least amount of $\mathrm{HCl}(2 \mathrm{~mL})$. A cold solution of $\mathrm{NaNO}_{2}$ below $5^{\circ} \mathrm{C}$ was then added to amine solution dropwise with continuous stirring. A solution of $0.01 \mathrm{~mol}$ of uracil was prepared by dissolving it in $\mathrm{NaOH}$ solution and then cooled to $0{ }^{\circ} \mathrm{C}$. The cold diazonium salt solution was added to uracil solution in $\mathrm{NaOH}$ kept at $0{ }^{\circ} \mathrm{C}$ (Scheme-I). The yellow coloured solid dye was filtered off and recrystallized from ethanol. The purity of product was checked by TLC. Yield: $80 \%$. IR $\left(\mathrm{KBr}, v_{\max }, \mathrm{cm}^{-1}\right): 1455(\mathrm{~N}=\mathrm{N}), 1677$ $(\mathrm{C}=\mathrm{O})$. UV $\left(\lambda_{\max }, \mathrm{MeOH}\right): 326 \mathrm{~nm} .{ }^{1} \mathrm{H}$ NMR $\left(\mathrm{DMSO}-d_{6}\right) \mathrm{ppm}$ : $\delta 2.23(3 \mathrm{H}) \mathrm{S}, 3.14(3 \mathrm{H}), 7.60-7.82(5 \mathrm{H}), 11.01(2 \mathrm{H}), 5.46$

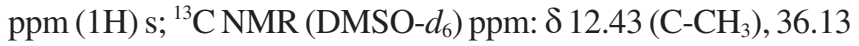
$\left(\mathrm{N}-\mathrm{CH}_{3}\right), 96.48,123.53(\mathrm{C}-\mathrm{N}), 123.15,125.92,126.71,128.43$, 128.99, 129.28 (C), 135.34 (C=C), 142.08, 151.42, 166.14 $(\mathrm{C}=\mathrm{O}), 164.26(\mathrm{C}=\mathrm{C})$. Elemental analysis of $\mathrm{C}_{15} \mathrm{H}_{14} \mathrm{~N}_{6} \mathrm{O}_{3}$ calcd. (found) \%: C, 55.19 (55.21); H, 4.30 (4.28); N, 25.75 (25.74); HRMS Calcd. (found): $[\mathrm{M}+\mathrm{H}]^{+} 327.568\left([\mathrm{M}+\mathrm{H}]^{+} 327.569\right)$ [29].

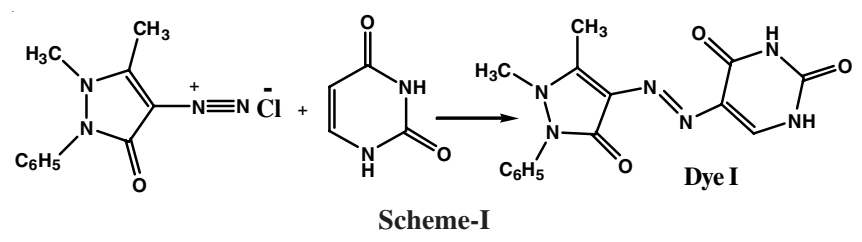

Synthesis of 6-amino-5-(1,5-dimethyl-3-oxo-2-phenyl2,3-dihydro-1 $H$-pyrazol-4-ylazo)-1 $H$-pyrimidine-2,4-dione (dye II): A solution of 4-aminoantipyrine $(0.01 \mathrm{~mol})$ was prepared in least amount of $\mathrm{HCl}(2 \mathrm{~mL})$. A cold solution of $\mathrm{NaNO}_{2}$ below $5{ }^{\circ} \mathrm{C}$ was then added to amine solution dropwise with continuous stirring. A solution of $0.01 \mathrm{~mol}$ of 6-aminouracil was prepared by dissolving in $\mathrm{NaOH}$ solution then cooled to $0{ }^{\circ} \mathrm{C}$. The cold diazonium salt solution was added to 6-aminouracil solution in $\mathrm{NaOH}$ kept at $0{ }^{\circ} \mathrm{C}$ (Scheme-II). The red coloured solid dye was filtered off and recrystallized from ethanol. The purity of product was checked by TLC. Yield: $78 \%$. IR $\left(\mathrm{KBr}, v_{\max }, \mathrm{cm}^{-1}\right)$ : $1429(\mathrm{~N}=\mathrm{N}), 1658(\mathrm{C}=\mathrm{O}) . \mathrm{UV}\left(\lambda_{\max }, \mathrm{MeOH}\right): 508 \mathrm{~nm} .{ }^{1} \mathrm{H}$ NMR (DMSO- $d_{6}$ ) ppm: $\delta 2.24(3 \mathrm{H}), 3.24(3 \mathrm{H}), 7.60-7.82(5 \mathrm{H}), 11.02$ $(2 \mathrm{H}), 5.46(1 \mathrm{H}), 8.34(2 \mathrm{H}) ;{ }^{13} \mathrm{C}$ NMR (DMSO- $\left.d_{6}\right) \mathrm{ppm}: \delta 11.23$ $\left(\mathrm{C}-\mathrm{CH}_{3}\right), 37.12\left(\mathrm{~N}^{-} \mathrm{CH}_{3}\right), 97.41,124.18(\mathrm{C}-\mathrm{N}), 120.01,124.21$, 127.30, 128.14, 130.17, 131.99 (C), 142.13, 152.61, 160.14 $(\mathrm{C}=\mathrm{O}), 167.15(\mathrm{C}=\mathrm{C}), 178.01\left(\mathrm{C}-\mathrm{NH}_{2}\right)$. Elemental analysis of $\mathrm{C}_{15} \mathrm{H}_{16} \mathrm{~N}_{7} \mathrm{O}_{3}$ calcd. (found) \%: C, 52.63 (52.64); $\mathrm{H}, 4.67$ (4.65); $\mathrm{N}, 28.65$ (28.63); HRMS Calcd. (found): $[\mathrm{M}+\mathrm{H}]^{+} 343.23$ ([M+H] ${ }^{+}$ 343.23).

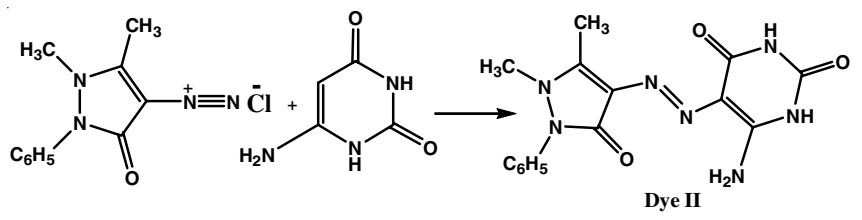

Scheme-II
Synthesis of 5-(3-hydroxy-pyridin-2-ylazo)-1H-primidine-2,4-dione (dye III): A solution of 2-amino-3-hydroxypyridine $(0.01 \mathrm{~mol})$ was prepared in the minimum amount of $\mathrm{HCl}(2 \mathrm{~mL})$. A cold solution of $\mathrm{NaNO}_{2}$ below $5{ }^{\circ} \mathrm{C}$ was then added to amine solution dropwise with continuous stirring. A solution of $0.01 \mathrm{~mol}$ of uracil was prepared by dissolving in $\mathrm{NaOH}$ solution then cooled to $0{ }^{\circ} \mathrm{C}$. The cold diazonium salt solution was added to uracil solution in $\mathrm{NaOH}$ kept at $0{ }^{\circ} \mathrm{C}$ (Scheme-III). The pink coloured solid dye was filtered off and recrystallized from ethanol. The purity of product was checked by TLC. Yield: $81 \%$. IR $\left(\mathrm{KBr}, v_{\max }, \mathrm{cm}^{-1}\right): 1438(\mathrm{~N}=\mathrm{N}), 1669$ $(\mathrm{C}=\mathrm{O})$. UV $\left(\lambda_{\max }, \mathrm{MeOH}\right): 480 \mathrm{~nm} .{ }^{1} \mathrm{H}$ NMR (DMSO- $\left.d_{6}\right) \mathrm{ppm}$ : $\delta$ 7.60-7.82 (3H), $11.01(2 \mathrm{H}), 5.46(1 \mathrm{H}), 9.37(1 \mathrm{H}) ;{ }^{13} \mathrm{C}$ NMR (DMSO- $d_{6}$ ) ppm: $\delta 100.01,124.36,125.89,138.75,141.36$, $142.75,152.91,155.36(\mathrm{C}-\mathrm{OH}), 164.89(\mathrm{C}=\mathrm{O})$. Elemental analysis of $\mathrm{C}_{9} \mathrm{H}_{8} \mathrm{~N}_{5} \mathrm{O}_{3}$ calcd. (found) \%: C, 46.15 (46.17); $\mathrm{H}, 3.40$ (3.38); N, 29.91 (29.92); HRMS Calcd. (found): $[\mathrm{M}+\mathrm{H}]^{+} 235.03$ $\left([\mathrm{M}+\mathrm{H}]^{+} 235.01\right.$.

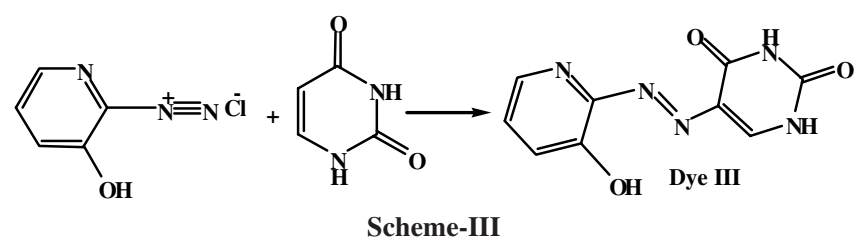

Synthesis of 2-(2-hydroxy-naphthalen-1-ylazo)pyridin-3ol (dye IV): A solution of 2-amino-3-hydroxypyridine (0.01 mol) was prepared in the minimum amount of $\mathrm{HCl}(2 \mathrm{~mL})$. A cold solution of $\mathrm{NaNO}_{2}$ below $5{ }^{\circ} \mathrm{C}$ was then added to amine solution dropwise with continuous stirring. A solution of 0.01 mol of $\beta$-naphthol was prepared by dissolving in $\mathrm{NaOH}$ solution then cooled to $0^{\circ} \mathrm{C}$. The cold diazonium salt solution was added to $\beta$-naphthol solution in $\mathrm{NaOH}$ kept at $0^{\circ} \mathrm{C}$ (Scheme-IV). The grey coloured solid dye was filtered off and recrystallized from ethanol. The purity of product was checked by TLC. Yield: 72 $\%$. IR $\left(\mathrm{KBr}, v_{\max }, \mathrm{cm}^{-1}\right): 1468(\mathrm{~N}=\mathrm{N}), 3392(\mathrm{O}-\mathrm{H}) . \mathrm{UV}\left(\lambda_{\max }\right.$, $\mathrm{MeOH}): 265 \mathrm{~nm} .{ }^{1} \mathrm{H}$ NMR (DMSO- $d_{6}$ ) ppm: $\delta$ 7.70-7.90 (9 $\mathrm{H}), 9.40(1 \mathrm{H}), 10.40(1 \mathrm{H}) ;{ }^{13} \mathrm{C}$ NMR (DMSO- $\left.d_{6}\right) \mathrm{ppm}: \delta 99.98$, 109.51, 116.16, 117.74, 120.13, 123.63, 125.12, 126.37, 126.53, 127.77, 128.98, 129.85, 134.61, 153.35, $159.12(\mathrm{C}-\mathrm{OH})$. Elemental analysis of $\mathrm{C}_{15} \mathrm{H}_{11} \mathrm{~N}_{3} \mathrm{O}_{2}$ calcd. (found) \%: $\mathrm{C}, 67.66$ (67.64); $\mathrm{H}, 4.51$ (4.50); N, 15.69 (15.70); HRMS Calcd. (found): [M+H] ${ }^{+}$ $267.13\left([\mathrm{M}+\mathrm{H}]^{+}\right.$267.11) [30].

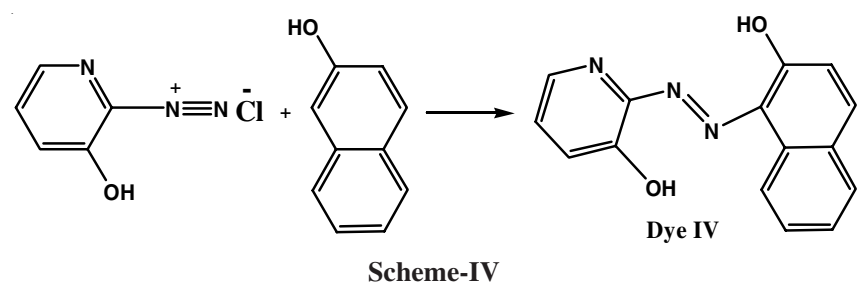

Synthesis of 4-(2,4-dihydroxy-phenylazo)-3-hydroxynaphthalene-1-sulfonic acid (dye V): A solution of 1-amino2-naphthol-4-sulphonic acid $(0.01 \mathrm{~mol})$ was prepared in least amount of $\mathrm{HCl}(2 \mathrm{~mL})$. A cold solution of $\mathrm{NaNO}_{2}$ below $5{ }^{\circ} \mathrm{C}$ was then added to amine solution dropwise with continuous stirring. A solution of $0.01 \mathrm{~mol}$ of resorcinol was prepared by 
dissolving in $\mathrm{NaOH}$ solution then cooled to $0^{\circ} \mathrm{C}$. The cold diazonium salt solution was added to resorcinol solution in $\mathrm{NaOH}$ kept at $0{ }^{\circ} \mathrm{C}$ (Scheme-V). The brown coloured solid dye was filtered off and recrystallized from ethanol. The purity of product was checked by TLC. Yield: $83 \%$. IR $\left(\mathrm{KBr}, v_{\max }, \mathrm{cm}^{-1}\right): 1459$ $(\mathrm{N}=\mathrm{N}), 3436(\mathrm{O}-\mathrm{H}) . \mathrm{UV}\left(\lambda_{\max }, \mathrm{MeOH}\right): 360 \mathrm{~nm} .{ }^{1} \mathrm{HNMR}$ (DMSO$\left.d_{6}\right)$ ppm: $\delta 6.10-7.70 \mathrm{ppm}(8 \mathrm{H}), 2.50(1 \mathrm{H}, \mathrm{s}), 8.70(1 \mathrm{H}, \mathrm{s}), 9.30$ $(1 \mathrm{H}, \mathrm{s}), 11.1(1 \mathrm{H}, \mathrm{s}),{ }^{13} \mathrm{CNMR}$ (DMSO- $\left.d_{6}\right)$ ppm: $\delta 108.12,109.34$, 117.43, 124.01, 124.35, 126.12, 126.51, 126.99, 127.32, 129.30, $133.05,136.73,145.08,145.98,152.28,152.31$ (C-OH). Elemental analysis of $\mathrm{C}_{16} \mathrm{H}_{12} \mathrm{~N}_{2} \mathrm{O}_{6} \mathrm{~S}$ calcd. (found) \%: C, 53.30 (53.32); H, 3.32 (3.30); N, 7.71 (7.70); S, 8.88 (8.87). HRMS Calcd. (found): $[\mathrm{M}+\mathrm{H}]^{+} 361.31\left([\mathrm{M}+\mathrm{H}]^{+}\right.$361.30) [31,32].

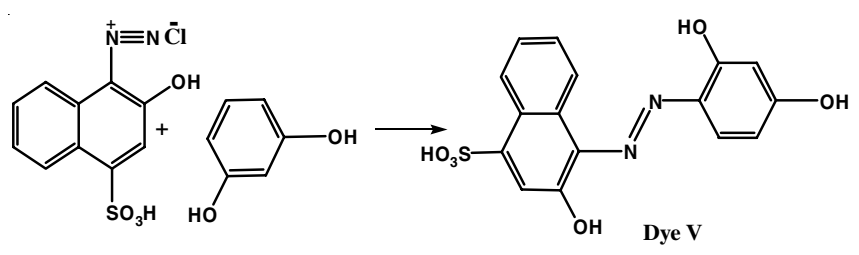

Scheme-V

Synthesis of N-(4-dimethylamino-benzylidene)-N-(2\{2-[(4-dimethylamino-benzylidine)amino]ethylamino\}ethyl)-ethane-1,2-diamine) (dye VI): A methanolic solution of triethylenetetramine $(0.01 \mathrm{~mol})$ and N,N-dimethylbenzaldehyde $(0.01 \mathrm{~mol})$ was heated under reflux on a water bath for $7 \mathrm{~h}$. The solution was kept at room temperature for $24 \mathrm{~h}$. Brown crystals separated was filtered and recrystallized from methanol (Scheme-VI). Yield: $85 \%$. IR (KBr, $\left.v_{\max }, \mathrm{cm}^{-1}\right): 1620(\mathrm{C}=\mathrm{N})$, $3021(\mathrm{~N}-\mathrm{H})$. UV $\left(\lambda_{\max }, \mathrm{MeOH}\right): 394 \mathrm{~nm}$.Elemental analysis of $\mathrm{C}_{24} \mathrm{H}_{36} \mathrm{~N}_{6}$ calcd. (found) \%: C, 70.58 (70.59); H, 8.82 (8.80); $\mathrm{N}, 20.58$ (20.57). HRMS Calcd. (found): $[\mathrm{M}+\mathrm{H}]^{+} 409.03$ $\left([\mathrm{M}+\mathrm{H}]^{+} 409.01\right)$.

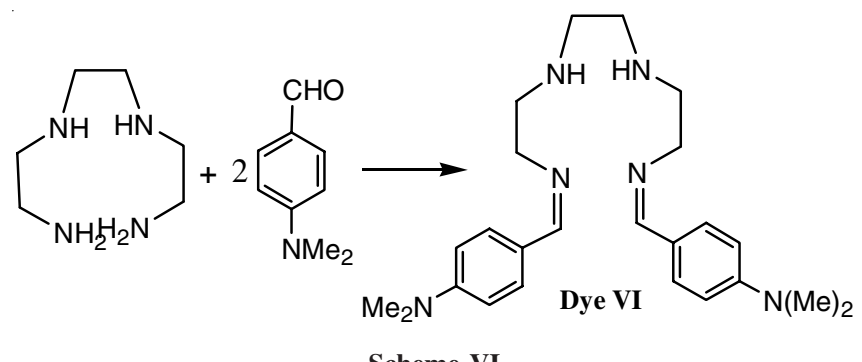

Dyeing of cotton fabric and dyeing properties: Efforts have been made to prepare disperse dyes derived from hetraryl compounds. Useful dyes in this respect are derived from 4-aminoantipyrine, uracil, 6-aminouracil, 2-amino-3-hydroxy-pyridine, 1-amino-2-naphthol-4-sulphonic acid and triethylenetetramine. The new dyes are studied for their dyeing properties and performance. The new dyes were applied on cotton fabric at $2 \%$ shade by high temperature technique and gave generally deep and bright intense hues, ranging from yellow to red.

Assessment of colour fastness: Satisfactory colour yields compared with commercial dyes applied under similar conditions were obtained at $2 \%$ depth of dye liquors were also achieved
$[33,34]$. Furthermore, the dyes gave excellent uniformity of colouration on cotton fabric without the use of retarding agent.

Fastness to washings at $50{ }^{\circ} \mathrm{C}$ and to perspiration shows excellent behaviour. Most of the dyes have a fair rubbing fastness 3 , which can be attributed to inadequate diffusion of the dye molecules into the fabric. Most of the dyes exhibit good sublimation and light fastness.

\section{Determination of dyeing and fastness}

Dyeing: The fabric was dyed with $2 \%$ dye (calculated on the weight of fabric), $1 \% \mathrm{NaCl}$ (as dispersing agent), kept at a liquor ratio of $20: 1$. The process was started at $60^{\circ} \mathrm{C}$ and the temperature was then raised to $130^{\circ} \mathrm{C}$ over $30 \mathrm{~min}$ and maintained for $1 \mathrm{~h}$. After cooling, the fabric was taken out and treated with a solution of $2 \%$ sodium bisulphite, $2 \% \mathrm{NaOH}$ and $0.1 \% \mathrm{NaCl}$ at $70{ }^{\circ} \mathrm{C}$ for $30 \mathrm{~min}$. Finally, the fabric was rinsed and dried at $60{ }^{\circ} \mathrm{C}$ [35].

Evaluation of fastness properties of a dye is done by measuring washing, light, rubbing and perspiration fastness values using wash wheel, xenoster, crock meter and prespirometer, respectively in terms of standard methods and these properties were measured using grey scale [36].

\section{Colour fastness tests}

Fastness to washing: A specimen of dyed cotton fabric was stitched between two pieces of undyed cotton fabric all of equal length and then washed at $50{ }^{\circ} \mathrm{C}$ for $30 \mathrm{~min}$. After soaping treatment, the specimen is removed, rinsed twice in cold water and then in cold running tap water. Squeezed and dried in air at a temperature not exceeding $60^{\circ} \mathrm{C}$. The staining on the undyed adjacent fabric was assessed according to the gray scale [37].

Fastness to perspiration: The samples were prepared by stitching a piece of dyed cotton fabric between two pieces of undyed cotton fabric, all of equal length and then immersed in the acidic ( $\mathrm{pH} 3.5$ ) or alkaline solution( $\mathrm{pH} 8.0$ ) for $30 \mathrm{~min}$. The staining on undyed adjacent fabric was assessed according to gray scale.

Fastness to rubbing: The dyed cotton fabric was placed on the base of crockmeter, so that it rested flatly on the abrasive cloth with its long dimension in the direction of rubbing. A square of white testing cloth was allowed to slide on the tested fabric back and froth 20 times by making 10 complete turns of the crank. For the wet rubbing test, the testing squares were thoroughly immersed in distilled water. The rest of the procedure was the same as in the dry test. The staining on the white testing cloth was assessed according to the gray scale [38].

Fastness to sublimation: Sublimation fastness was measured with an iron tester.The samples were prepared by stitching a piece of dyed cotton fabric between two pieces of undyed cotton, all of equal length and then treated at 180 and $210^{\circ} \mathrm{C}$ after every $1 \mathrm{~min}$. Any staining on undyed adjacent fabric or change in tone was assessed according to gray scale.

Fastness to light: Light fastness was determined by exposing the dyed polyester on a Xenotest 150 (original Hanau, Chamber temperature: $25-30^{\circ} \mathrm{C}$; black panel temperature: $60^{\circ} \mathrm{C}$; relative humidity: 50-60\%; dark glass UV filter system) for $40 \mathrm{~h}$. The change in colour was assessed according to gray scale [39]. 
TABLE-1

FASTNESS PROPERTIES OF THE DYES ON COTTON FABRIC

\begin{tabular}{|c|c|c|c|c|c|c|c|c|c|c|c|c|c|c|c|}
\hline \multirow[b]{3}{*}{ Dye } & \multicolumn{7}{|c|}{ Washing } & \multirow{2}{*}{\multicolumn{2}{|c|}{ Perspiration }} & \multirow{2}{*}{\multicolumn{2}{|c|}{ Rubbing }} & \multicolumn{3}{|c|}{ Sublimation fastness } & \multirow[b]{3}{*}{$\begin{array}{l}\frac{1}{0} \\
8 \\
\frac{7}{6} \\
\frac{0}{3}\end{array}$} \\
\hline & & & & Sta & g on & & & & & & & \multirow[b]{2}{*}{ 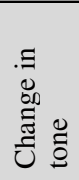 } & \multicolumn{2}{|c|}{ Staining at } & \\
\hline & 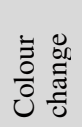 & $\begin{array}{l}\overline{8} \\
0 \\
3\end{array}$ & $\frac{0}{\sqrt[0]{3}}$ & $\begin{array}{l}\frac{\overline{0}}{0} \\
\frac{\delta}{0} \\
0\end{array}$ & $\frac{\overline{0}}{\bar{Z}}$ & 泀 & 胥 & $\frac{0}{\frac{0}{0}}$ & 武 & $\overrightarrow{1}$ & $\overline{3}^{\overline{0}}$ & & $\stackrel{\circ}{\infty}$ & $\frac{\stackrel{O}{\sim}}{\sqrt{n}}$ & \\
\hline I & 1 & $4-5$ & $4-5$ & $4-5$ & $4-5$ & $4-5$ & $4-5$ & $4-5$ & $4-5$ & 3 & $2-3$ & 4 & 4 & $3-4$ & $1-3$ \\
\hline II & 1 & $4-5$ & $4-5$ & $4-5$ & $4-5$ & $4-5$ & $4-5$ & $4-5$ & $4-5$ & 3 & $2-3$ & $4-5$ & 4 & $3-4$ & 5 \\
\hline III & 1 & $4-5$ & $4-5$ & $4-5$ & $4-5$ & $4-5$ & $4-5$ & $4-5$ & $4-5$ & 3 & $2-3$ & $4-5$ & $4-5$ & 4 & $1-3$ \\
\hline IV & 1 & $4-5$ & $4-5$ & $4-5$ & $4-5$ & $4-5$ & $4-5$ & 4 & 4 & 3 & $2-3$ & $4-5$ & $4-5$ & $4-5$ & 5 \\
\hline $\mathrm{V}$ & 1 & $4-5$ & $4-5$ & $4-5$ & $4-5$ & $4-5$ & $4-5$ & $4-5$ & $4-5$ & 3 & $2-3$ & 4 & $4-5$ & $4-5$ & 5 \\
\hline VI & 1 & $4-5$ & $4-5$ & $4-5$ & $4-5$ & $4-5$ & $4-5$ & 4 & 4 & 3 & $2-3$ & $4-5$ & 4 & 4 & 3 \\
\hline
\end{tabular}

\section{RESULTS AND DISCUSSION}

The above mentioned azo dyes provide wide range of colour with good levelness, brightness and depth on dyeing cotton fabrics. The nature and position of substituents present on the diazotized compound and coupling components has great influence on shade of dyeing $[40,41]$. The heteroatoms present in the ligand structure also results in the bathochromicity and leads to the brightness of shades. From the results (Table-1), it is revealed that dyes have fair to good fastness properties to light, washing, perspiration, rubbing and sublimation. The fastness properties of dyeing are correlated with the structure of the dye and substrate to which it is applied [42].

Dye I to V contains azo group and VI contains azomethine group as chromophore. Dye I and II contains carbonyl group, dye II and III contains amino group, IV and V contains hydroxyl group, $\mathrm{V}$ contains sulfonic acid group and VI contains NH group as well as $\mathrm{N}(\mathrm{Me})_{2}$ groups. Such groups often attatched to chromophores modify colours to molecules. In cotton fabrics, these dyes gets attached to fabric by hydrogen bonding. Dye VI is long enough and straight so that they can line up with cellulose fibers and form several hydrogen bonds.

An important property of textiles is their light fastness which is affected by several factors such as physico-chemical characteristics of fibers, chemical structure of dyes the wavelength distribution of impinging radiation and several other environmental conditions [43]. In this present case, the reported dyes exhibit wide range of fastness from 1 to 5 on cotton fabrics and are significantly affected by nature of substituents. The light fastness depends on degree of aggregation of dye within the fabric, nature of fabric in which it is dispersed, characteristics of incident radiation, molecular structure, molecular size and substantivity [41]. In this work, the best light fastness was obtained for dye II, IV and V. This agrees with the notion that azo compounds appended with electron withdrawing substituents on the diazo components are less prone to photofading [44]. The presence of electron withdrawing group such as sulfonic acid adjacent to diazotizable amino group has a bathochromic influence on the shades of these dyes on fabric and is useful for better dispersability and dyeability.

The solubility and rate of movement of dye out of the fabric during washing depends on the size of dye molecules, the type of mechanical linkage between dye and fiber, and the type of charge on dye, which in turn depends on the electron donating or electron attracting character of substituents. If the fabric is crystalline and hydrophobic in nature it inhibit the diffusion of dye out of the fiber, thus better ratings are obtained. The remarkable degree of brightness of the fabric after washing is indicative of good penetration and the excellent affinity of the dye to different fabrics [45].

The best results are shown for perspiration fastness as the dye molecules penetrates deeper into fabric. The rubbing fastness depends on the presence of loose dye particles on the surface of fabric. It depends on the substantivity of dye for the fabric, which in turn depends on molecular size, geometry and polarity of molecule [46]. Rubbing fastness property is moderate in dry and fair to moderate in wet condition. Sublimation fastness are good to excellent at $180{ }^{\circ} \mathrm{C}$ and moderate to excellent at $210^{\circ} \mathrm{C}$ as dye molecules are less stable at higher temperature.

Dye $\mathrm{V}$ having sulfonic acid group as well as three hydroxyl group shows better result to fastness properties among the discussed dyes in this work. The molecular size, geometry and molecular mass also enhances the discussed properties.

\section{Conclusion}

Azo dyes derived from various heterocyclic amines have been synthesized and characterized. These dyes gave yellow hues with good levelness, brightness and depth on fabrics. The variation in the hues of the dyed fabrics results from both the nature and position of the substituent present on the azo coupling ring. All the fastness properties are inter-related since they depend on rate of diffusion of dye into fabric. This rate is a function of geometry of dye molecule, small molecular size, the intrinsic property of heterocyclic ring, the electron withdrawing character of an appropriately substituted groups and hydrophobic nature of heterocyclic ring which is useful for better dispersability, dyeability and intrinsic conjugation in structure leading to fair to excellent properties. All the dyes have higher rating. The washing fastness of dyes are very good compared with commercial dyes. From the results, it can be conclued that dye IV and V have good assessment values for fastness properties that can be successfully used for dyeing textile fabrics,mainly on account of the facility and low-cost of the dyes synthesis, ease of application and overall versatility of their use.

\section{ACKNOWLEDGEMENTS}

The authors are thankful to Department of Chemistry, University College, Trivandrum, India for instrumental facilities under FIST DST, SITRA Coimbatore, India and SAIF Cochin 
for analytical facilities. One of the authors (VGV) is thankful to UGC for the Faculty Development Programme support.

\section{CONFLICT OF INTEREST}

The authors declare that there is no conflict of interests regarding the publication of this article.

\section{REFERENCES}

1. J. Tao, G. Mao and L. Daehne, J. Am. Chem. Soc., 121, 3475 (1999); https://doi.org/10.1021/ja983842v.

2. A. Navarro and F. Sanz, Dyes Pigments, 40, 131 (1999); https://doi.org/10.1016/S0143-7208(98)00048-5.

3. K.L. Georgiadou and E.G. Tsatsaroni, Dyes Pigments, 50, 93 (2001); https://doi.org/10.1016/S0143-7208(01)00034-1.

4. J.A. Mikroyannidis, D.V. Tsagkournos, S. Sharma, A. Kumar, Y.K. Vijay and G.D. Sharma, Sol. Energy Mater. Sol. Cells, 94, 2318 (2010); https://doi.org/10.1016/j.solmat.2010.08.001.

5. H. Dincalp, F. Toker, I. Durucasu, N. Avcibasi and S. Icli, Dyes Pigments, 75, 11 (2007);

https://doi.org/10.1016/j.dyepig.2006.05.015.

6. D. Zhang, M. Zhang, Z. Liu, M. Yu, F. Li, T. Yi and C. Huang, Tetrahedron Lett., 47, 7093 (2006); https://doi.org/10.1016/j.tetlet.2006.07.080.

7. B.A. Trofimov, E.Y. Schmidt, A.I. Mikhaleva, A.M. Vasil'tsov, A.B. Zaitsev, N.S. Smolyanina, E.Y. Senotrusova, A.V. Afonin, I.A. Ushakov, K.B. Petrushenko, O.N. Kazheva, O.A. Dyachenko, V.V. Smirnov, A.F. Schmidt, M.V. Markova and L.V. Morozova, Eur. J. Org. Chem., 4021 (2006); https://doi.org/10.1002/ejoc.200600357.

8. M. Bhaskar, A. Gnanamani, R.J. Ganeshjeevan, R. Chandrasekar, S. Sadulla and G. Radhakrishnan, J. Chromatogr. A, 1018, 117 (2003); https://doi.org/10.1016/j.chroma.2003.08.024.

9. M. Dakiky and I. Nemcova, Dyes Pigments, 44, 181 (2000); https://doi.org/10.1016/S0143-7208(99)00086-8.

10. M.M. Russew and S. Hecht, Adv. Mater, 22, 3348 (2010); https://doi.org/10.1002/adma.200904102.

11. E. Kleinpeter, U. Bolke and J. Kreicberga, Tetrahedron, 66, 4503 (2010); https://doi.org/10.1016/j.tet.2010.04.067.

12. X. Li, Y. Wu, D. Gu and F. Gan, Dyes Pigments, 86, 182 (2010); https://doi.org/10.1016/j.dyepig.2010.01.002.

13. J. Griffiths, Colour and Constitution of Organic Molecules; Academic Press, London, p. 186 (1976).

14. A.D. Towns, Dyes Pigments, 42, 3 (1999); https://doi.org/10.1016/S0143-7208(99)00005-4.

15. V. Arun, P.P. Robinson, S. Manju, P. Leeju, G. Varsha, V.K.K.M. Digna and K.K.M. Yusuff, Dyes Pigments, 82, 268 (2009); https://doi.org/10.1016/i.dyepig.2009.01.010.

16. H.S. Bhatti and S. Seshadri, Color. Technol., 120, 151 (2004); https://doi.org/10.1111/j.1478-4408.2004.tb00221.x.

17. V.H. Patel, M.P. Patel and R.G. Patel, Dyes Pigments, 52, 191 (2002); https://doi.org/10.1016/S0143-7208(01)00068-7.

18. D.R. Patel and K.C. Patel, Dyes Pigments, 90, 1 (2011); https://doi.org/10.1016/j.dyepig.2010.10.013.

19. D.R. Patel and K.C. Patel, Arab. J. Chem., 76, 1 (2011).
20. D.R. Patel and K.C. Patel, Serb. Chem. Soc., 76, 177 (2011) https://doi.org/10.2298/JSC090225021P.

21. M.M. Parekh and K.C. Maheria, J. Sci. Ind. Res., 70, 525 (2010).

22. G.B. Bagihalli, P.G. Avaji, S.A. Patil and P.S. Badami, Eur. J. Med. Chem., 43, 2639 (2008); https://doi.org/10.1016/j.ejmech.2008.02.013.

23. E. Rodríguez-Fernández, J.L. Manzano, J.J. Benito, R. Hermosa, E. Monte and J.J. Criado, J. Inorg. Biochem., 99, 1558 (2005); https://doi.org/10.1016/j.jinorgbio.2005.05.004.

24. Z.H. Chohan, S.H. Sumrra, M.H. Youssoufi and T.B. Hadda, Eur. J. Med. Chem., 45, 2739 (2010); https://doi.org/10.1016/j.ejmech.2010.02.053.

25. J. Park and D.J. Smith, J. Soc. Dyers Colourists, 90, 431 (1974); https://doi.org/10.1111/j.1478-4408.1974.tb03179.x.

26. C.L. Bird, J. Soc. Dyers Colourists, 70, 68 (1954); https://doi.org/10.1111/j.1478-4408.1954.tb02017.x.

27. V. Sadasivan and M. Alaudeen, Indian J. Chem., 46A, 1959 (2007).

28. G. Kaupp, J. Schmeyers and J. Boy, J. Prakt. Chem., 342, 269 (2000); https://doi.org/10.1002/(SICI)1521-3897(200003)342:3<269::AIDPRAC269>3.0.CO;2-0.

29. V.G. Vidya, S.S. Meena, P. Bhatt, V. Sadasivan and S. Mini, AIP Conf. Proc., 1536, 1009 (2013); https://doi.org/10.1063/1.4810574.

30. S. Mini, S.S. Meena, P. Bhatt, V. Sadasivan and V.G. Vidya, AIP Conf. Proc., 1620, 1011 (2013); https://doi.org/10.1063/1.4810575.

31. V.G. Vidya, V. Sadasivan, S.S. Meena and P. Bhatt, AIP Conf. Proc., 1620, 622 (2014); https://doi.org/10.1063/1.4898308.

32. S. Mini, V. Sadasivan, S.S. Meena and P. Bhatt, AIP Conf. Proc., 1536, 322 (2014); https://doi.org/10.1063/1.4898259.

33. M.A. Metwally, Dyes Pigments, 60, 249 (2004); https://doi.org/10.1016/S0143-7208(03)00153-0.

34. H.R. Maradiya, J. Saudi Chem. Soc., 14, 77 (2010); https://doi.org/10.1016/j.jscs.2009.12.012.

35. V.A. Shenai, Chemistry of Dyes and Principles of Dyeing, Sevak Publication, Bombay, India (1973).

36. Anon, Standard Methods for Determination of Colour Fastness of Textiles and Leather, Society of Dyers and Colourists Publication Bradford, England (1990)

37. AATCC Test method, p. (1961).

38. Indian Standard ISO, p. 765 (1979).

39. Standard Rest Method BS 1006-1978; UK, ISO 105-1995.

40. B.C. Dixit, H.M. Patel and D.J. Desai, J. Serb. Chem. Soc., 72, 119 (2007); https://doi.org/10.2298/JSC0702119D.

41. H.R. Maradiya and V.S. Patel, Bull. Chem. Technol., 21, 57 (2002).

42. G. Hallas and A.D. Towns, Dyes Pigments, 35, 45 (1997); https://doi.org/10.1016/S0143-7208(96)00088-5.

43. M.R. Massafra, E. Selli, S. Salsa and B. Marcandalli, Dyes Pigments, 40, 171 (1999); https://doi.org/10.1016/S0143-7208(98)00045-X.

44. P.F. Gordon and P. Gregory, Organic Chemistry in Colour, Springer-Verlag, New York (1983).

45. H.R. Maradiya, Turk. J. Chem., 25, 441 (2001) 